\title{
P364: Injection safety and medical waste management in health care institutions in Guinea. (Guinea Conakry)
}

D Malal

From 2nd International Conference on Prevention and Infection Control (ICPIC 2013)

Geneva, Switzerland. 25-28 June 2013

\section{Objectives}

This study of the application of quality standards in the process of seeking care aims to contribute to improving the safety of injections, dressings and biomedical waste management in health institutions.

\section{Methods}

This is a descriptive study on the cross-device management services offered in nursing health facilities. The technique used for data collection is that of Interview. It ran from a questionnaire on the device provides nursing care in nine health facilities targets. This is a sample having a size of 52 subjects distributed among the strata according to their size represented by the staff working in maternity services health facilities drawn.

\section{Results}

The main results are:

i) The professional nursing is the most dominant with $34.59 \%$, ii) Approximately $20 \%$ of respondents are on the verge of retirement, and $15 \%$ over 50 years, iii) The ability to recognize the workers through their work clothes is very low, iv) There is a weakness in the procedures for dispensation injections and dressings, v) Inadequate hand washing device (38\%), vi) Low waste identification based on garbage bags and transportation inadequate, vii) Disinfection of medical devices violating procedures, viii) Low availability of clean cloth, ix) Acts and treatment protocols used infrequently, and $\mathrm{x}$ ) A third of health professionals do not have standards for the prevention of infectious risk.

Universty of Conakry, Conakry, Guinea

(c) 2013 Malal; licensee BioMed Central Ltd. This is an Open Access article distributed under the terms of the Creative Commons Attribution License (http://creativecommons.org/licenses/by/2.0), which permits unrestricted use, distribution, and reproduction in any medium, provided the original work is properly cited.

\section{Conclusion}

Renew the number of agents maternity; Train staff in the use of care protocols; Improve water availability, garbage bags and disinfection equipment, injection materials and dressing; Strengthen individual protection measures.

\section{Disclosure of interest}

None declared.

Published: 20 June 2013

doi:10.1186/2047-2994-2-S1-P364

Cite this article as: Malal: P364: Injection safety and medical waste management in health care institutions in Guinea. (Guinea Conakry). Antimicrobial Resistance and Infection Control 2013 2(Suppl 1):P364.

Submit your next manuscript to BioMed Central and take full advantage of:

- Convenient online submission

- Thorough peer review

- No space constraints or color figure charges

- Immediate publication on acceptance

- Inclusion in PubMed, CAS, Scopus and Google Scholar

- Research which is freely available for redistribution Submit your manuscript at
www.biomedcentral.com/submit C Biomed Central 